\section{Labelling and marketing of bivalve and gastropod molluscs retailed in Sardinia, Italy between 2009 and 2013}

\author{
Domenico Meloni \\ Department of Veterinary Medicine, \\ University of Sassari, Italy
}

\begin{abstract}
The aim of the present survey was to investigate the correct enforcement of the Community rules on the labelling and marketing of bivalve and gastropod molluscs retailed in Sardinia, Italy between 2009 and 2013. A total of 1500 packages and labels for live bivalve and gastropod molluscs were considered. A total of 375 labels (25\%) presented non-compliance concerning the wrong trade name and additional wrong or missing information. The highest percentage of anomalous labels has been detected in small-scale retail shops (35\%) and open-air markets (25\%) compared with the big retailing chains (20\%). The $5 \%$ of packages were not in compliance with the European Community rules on packaging of bivalve and gastropod molluscs. The high percentage of non-compliance with the European regulations on labelling results is a strong limitation for the consumers and highlights the need to improve the control system about labelling of seafood products.
\end{abstract}

\section{Introduction}

Worldwide bivalve production has consistently increased over the years from 7.1 million in 1995 to 15.1 million in 2012 , and the consumer demand is expected to further increase in the next future (Anacleto et al., 2014; FA0, 2014). In Europe, Italy is the third largest European producer of bivalve molluscs, after Spain and France (Billé et al., 2013). In general, consumption of bivalves in the EU is highest in southern European countries like Spain, France, Portugal, Italy, and Greece (FA0, 2014). Consumption of bivalves in Eastern Europe member States is relatively low compared to other parts of the EU because most consumers are not familiar with these products. As the economic situation in most of these countries is improving, there are opportunities for positioning bivalves in the highend segment, such as high-class restaurants or hotels (FAO, 2014). In Italy, bivalve molluscs represent the most important farmed seafood resource, representing over half of the total national aquaculture production (Meloni et al., 2010), mainly composed by Japanese carpet shells (R. philippinarum) and Mediterranean mussels (M. galloprovincialis). Italy is the leading European producer of clams and the second in the world after China. Moreover, it is the third largest worldwide producer of mussels, after China and Spain (Billé et al., 2013). Clams are mainly farmed in Veneto and Emilia Romagna regions, while the production of mussels is typical of Emilia Romagna, Veneto, Sardinia and Apulia regions (Meloni et al., 2010).

In Sardinia, the production of bivalve molluscs dated since after the World War I. Nowadays, the regional shellfish sector is well consolidated: in 2008, molluscs production accounted for $83 \%$ of the aquaculture species farmed in Sardinia and EUR 19,723.715,00 by value (Sardegna Agricoltura/Laore, 2009). The regional shellfish production rests almost exclusively on Mediterranean mussel $M$. galloprovincialis: in 2008 Sardinia produced 11,000 tonnes of mussels, and significantly increased $(+60 \%)$ in the late 20 years (Sardegna Agricoltura/Laore, 2009). Sardinia concentrated the major part of the regional mollluscs production at the beginning of summer. In the rest of the year, the current availability of bivalve molluscs is insufficient to cope with consumers demand, thus requiring the import of several species (e.g. Mediterranean and Blue mussels, oysters, Japanese carpet shells) farmed in Northern Italy or imported from France, Spain and Greece (Meloni et al., 2010). As a matter of fact, several regulatory issues related to the proper identification and labelling of the different species have been issued. Moreover, in the local small-scale retail shops and open-air markets the use of the local identification names instead of the official trade names of the different species of bivalves and gastropods is very frequent.

European Community Regulations (EC) 104/2000 and 2065/2001 (European Commission, 2000, 2001) provided the detailed rules for consumer information about bivalve and gastropod molluscs through improved labelling at retail level. Live bivalve and gastropod molluscs may not be placed on the market for retail sale otherwise than via a dispatch centre, where an identification mark must be applied in accordance with Regulation (EC) 853/2004 (European Commission, 2004a). Bivalve and gastropod molluscs must be supplied with a waterproof label, including the identification mark. The following information must be provided: i) trade and scientific name of the species accepted in the national territory; ii) production method; iii) origin (in the case of bivalves, the country where it is produced must be referenced); iv) date of minimum durability replaced by the entry (these animals must be alive when sold); v) EU
Correspondence: Domenico Meloni, Department of Veterinary Medicine, University of Sassari, via Vienna 2, 07100 Sassari, Italy.

Tel: +39.079 .229570 - Fax: +39.079 .229458 .

E-mail: dmeloni@uniss.it

Key words: Labelling; Packaging; Marketing; Bivalve molluscs; Gastropod molluscs.

Received for publication: 22 December 2014. Revision received: 25 February 2015.

Accepted for publication: 25 February 2015.

This work is licensed under a Creative Commons Attribution 3.0 License (by-nc 3.0).

CCCopyright D. Meloni, 2015

Licensee PAGEPress, Italy

Italian Journal of Food Safety 2015; 4:4923

doi:10.4081/ijfs.2015.4923

approval number of the dispatch centre; vi) EU seller (name or business name and address of the manufacturer, packager or seller established in the $\mathrm{EU}$ ); vii) lot number frequently replaced by the date of packaging, comprising at least the day and the month; viii) netweight. The contents of labelling must be provided in the language of the country where the product is marketed. Live bivalve and gastropod molluscs must be wrapped under satisfactory conditions of hygiene. The wrapping material must be strong enough to give adequate protection to the molluscs and not to impair their organoleptic characteristics. Moreover, the wrapping material must be capable of not transmitting to the bivalve and gastropod molluscs substances harmful to human health. All wrappings of live bivalve and gastropod molluscs must be sealed and remain sealed all along the molluscs supply chain from the dispatch centre until delivery to the consumer or retailer.

In Sardinia, the Department of Hygiene and Health and Social Welfare has recently issued the 2014 revision of the Regional plan for the monitoring and surveillance of the production and marketing of shellfish (Sardegna Salute, 2014). This plan integrates the Italian Guidelines for the application of Reg. (EC) 853/2004 and Reg. (EC) 854/2004 (European Commission, 2004a, 2004b) and included issues resulting from previous experiences in the management of the shellfish supply chain in other Italian regions adapted to the peculiarities of Sardinia. The Regional plan provides guidance for the application of the Community rules on food safety along the various stages of the shellfish supply chain including labelling and marketing.

The aim of the present study was to investigate the correct enforcement of the European Community rules on the labelling, packaging 
and marketing of bivalve and gastropod molluscs retailed in Sardinia between 2009 and 2013.

\section{Materials and Methods}

The survey was carried out between 2009 and 2013 by using the method of digital photo documentation. Photographs of bivalve and marine gastropods molluscs packages, with the respective labels in view, were taken with a digital camera Nikon D3100 (Nikon Corp., Tokyo, Japan). To assess the conformity of the species with the trade name reported in the labels, a preliminary morphological analysis of the molluscs was performed, followed by the accurate analysis of the photographs. Overall, the compliance of 1500 labels and packages with current legislation has been assessed at the retail sale stage (Table 1). In detail, n. 800 packages with the respective labels have been considered at the fish shops of 10 big retailing chains and n. 400 at 40 local small-scale retail shops located in the province of Sassari. The remaining $n .300$ packages with the respective labels have been considered at 3 open-air fish markets located in the towns of Cagliari, Sassari and Alghero (SS). Altogether, n. 1100 packages of bivalve molluscs and n. 400 of gastropod molluscs have been considered. The presence of non-compliance with the European Community rules on labelling, packaging and marketing of bivalve and gastropod molluscs has been expressed as a percentage of total packages and labels examined and was also evaluated with respect to its distribution in the different typology of retail shops.

\section{Results and Discussion}

\section{Labelling of bivalve and gastropod molluscs}

Out of the 1500 examined labels between 2009 and 2013, n. 375 (25\%) were not in compliance with the European Community rules on the labelling of bivalve and gastropod molluscs (Table 2). According to Orefice et al. (2005) and Dambrosio et al. (2012), our survey highlighted the highest percentage of noncompliances in the labels examined at the small-scale retail shops (35\%) and open-air fish markets (25\%). The non-compliances detected at the big retailing chains accounted for $20 \%$ (Table 2). The prevalent non-compliances on labelling were related to the incorrect or incomplete indication of the official trade name as provided by the Italian Ministerial Decree of the Ministry of Agriculture of August 12, 2011 (IMAFFP, 2011). The most frequent case of mislabelling regarded $M$. edulis specimens marketed as M. galloprovincialis, when the amount of production of Mediterranean mussels is insufficient to cope with consumers demand, thus requiring the import of Blue mussels from Spain and Greece. Extremely variable in shape and colour, in some $M$. edulis populations, the shells can be large, flat, and have more concave basal line, giving the shell a rounded shape similar to $M$. galloprovincialis shells. Other non-compliances on labelling were related to the incorrect or incomplete indication of the FAO alpha- 3 code of each species and the frequent use of the local and dialectal identification names instead of the official trade names for several species of bivalves and gastropods marketed in the local small-scale retail shops and open-air markets. Member States shall indicate, where applicable, any other name or names that are accepted or permitted locally or regionally together with the name of the species in the official language or languages of the Member State designated as trade name. In the list of the trade names accepted in Italy together with their scientific names (IMAFFP, 2011), any other names accepted or permitted locally or regionally were reported. Regarding the bivalve molluscs, the most frequent cases of replacement, regarded the use of the dialectal names of Cocciula or Arsella instead of the official trade name Vongola verace for the clams Grooved carpet shell and Japanese carpet shell. The most common cases of mislabelling in the gastropods regarded the usage of the dialectal name of Boccone maschio instead of the official trade name Murice spinoso for the Purple dye murex and the dialectal names of Boccone trade name Murice for the Banded murex.

Packaging and marketing of bivalve and gastropod molluscs

Out of the 1500 examined packages between 2009 and 2013, the majority of packages were wrapped under satisfactory conditions of hygiene. Only n.75 wrappings (5\%) were not in compliance with the Community rules on packaging and marketing of bivalve and gastropod molluscs (Table 2). The highest percentage of non-compliances was pointed out in the packages examined at the small-scale retail shops (10\%) and open-air fish markets (8\%). The non-compliances detected at the big retailing chains accounted for $1 \%$ (Table 2). The most frequent non-compliances concerned the opening of the ready-made molluscs packages for retail and the sale of loose bivalves and gastropods. According to the Reg. (EC) 853/2004 (European Commission, 2004a), wrappings of live bivalve and gastropod molluscs must remain sealed all along the molluscs supply chain. No re-immersion in water of wrappings packaged for retail sale was pointed out.

\section{Conclusions}

The results of the present survey are in agreement with previous studies (Dambrosio et al. 2012): the lowest percentage of non-compliances detected at the big retailing chains should be related to the strict procedures for the referencing of the suppliers and to the specific training programmes of the staff in charge to the fish shops of the big retailing chains. These proce-

Table 1. Total of labels included in the survey and distribution according to type of retail stores and molluscs.

\begin{tabular}{lccc} 
Retail stores & Molluses & \\
Fish shops of big retailing chains & 600 & 200 & 800 \\
Local small-scale retail shops & 300 & 100 & 400 \\
\hline Open-air fish markets & 200 & 100 & 300 \\
Total & 1100 & 400 & 1500 \\
\hline
\end{tabular}

femmina or Femminella instead of the official dures are essential in order to limit the inaccuTable 2. Mislabelling and incorrect packaging and marketing of bivalve and gastropod molluscs according to typology of retail stores.

\begin{tabular}{lcc}
\hline Retail stores & $\begin{array}{c}\text { Mislabelling (\%) } \\
\text { Fish shops of big retailing chains }\end{array}$ & $\begin{array}{c}\text { Incorrect packaging } \\
\text { and marketing (\%) }\end{array}$ \\
Local small-scale retail shops & $160(20)$ & $10(1)$ \\
\hline Open-air fish markets & $75(35)$ & $40(10)$ \\
Total & $375(25)$ & $25(8)$ \\
\hline
\end{tabular}


racies in labelling in the preliminary stages of the supply chain and the presence of non-compliances in the fish shops at the retail stage. The non-compliances highlighted in this study are in deep disagreement with the aim of the European Community legislation on traceability and marketing of bivalve and gastropod molluscs, i.e. to provide all the essential information to the consumers. As a consequence, consumers' freedom of choice and possibility to purchase consciously are strongly limited. The results of the present study pointed out the need for an improvement of the control system about labelling of shellfish retailed in Sardinia and highlighted the necessity of more appropriate food business operators training courses on correct labelling and marketing of bivalve and gastropod molluscs. Food business operators should be aware of the potential consequences resulting from incorrect or incomplete labelling and of the penalties provided by the European Community rules in case of commercial frauds.

\section{References}

Anacleto P, Barrento S, Nunes ML, Rosa R, Marques A, 2014. Portuguese consumers' attitudes and perceptions of bivalve molluscs. Food Control 41:168-77.

Bille L, Ceolin C, Dalla Pozza M, Toson M, Trolese M, Arcangeli G, 2013. Risultati del piano di monitoraggio per il controllo delle patologie dei molluschi nel periodo 2007 2012. In: Proc. of the 2nd National Congress of SIRAM, Cesenatico, Italy.
Dambrosio A, Anaclerio D, Quinto M, Centoducati G, Errico L, Girolamo LG, Normanno G, 2012. Indagine sull'applicazione delle norme sull'etichettatura di prodotti ittici commercializzati al dettaglio in Puglia: risvolti normativi e igienicosanitari. Ind Aliment-Italy 51:40-6.

European Commission, 2000. Council Regulation of 17 December 1999. (21st January 2000). On the common organization of the markets in fishery and aquaculture products, 104/2000/EC. In: Official Journal, L 17/22.

European Commission, 2001. Commission Regulation of 22 October 2001. (23rd October 2001). Laying down detailed rules for the application of Council Regulation (EC) No 104/2000 as regards informing consumers about fishery and aquaculture products, 2065/2001/EC. In: Official Journal, L 278/6.

European Commission, 2004a. Council Regulation of the European Parliament and of the Council laying down specific hygiene rules for on the hygiene of foodstuffs, 853/2004/EC. In: Official Journal, L $139 / 55$.

European Commission, 2004b. Council Regulation of the European Parliament and of the Council laying down specific rules for the organization of official controls on products of animal origin intended for human consumption, 854/2004/EC. In: Official Journal, L 226/83-127.

FA0, 2014. The state of world fisheries and aquaculture 2014: opportunities and challenges. United Nations Food and
Agriculture Organization Available from: http://www.fao.org/3/a-i3720e/index.html

IMAFFP, 2011. Assignment of the Italian trade name to fish species of commercial interest, in accordance with Regulation (EC) 104/2000, and Title I of Regulation (EC) 2065/2001. Italian Mnistry of Agricultural, Food and Forestry Policies, Rome, Italy.

Meloni D, Mureddu A, Pisanu M, Sferlazzo G, Serra S, Tempesta A, Piras F, Virgilio S, Mazzette R, 2010. Valutazione dell'efficacia dei sistemi di depurazione nei confronti di E. coli, Salmonella spp e Vibrio spp in mitili allevati nel golfo di Olbia. Il Pesce 5/10:165-72.

Orefice G, Canova A, Garnero A, Dugoni W, 2005. Un'esperienza di vigilanza nelle pescherie. Available from: http://www. ordiniveterinaripiemonte.it/rivista/05n06/ 06.htm

Sardegna Agricoltura/Laore, 2009. Il comparto dell'acquacoltura in Sardegna alla luce dei risultati dell'indagine conoscitiva. Available from: http://www.sardegnaagricoltura.it/documenti/14_43_200912011750 44.pdf

Sardegna Salute, 2014. Piano regionale per la vigilanza ed il controllo sanitario della produzione e commercializzazione dei molluschi bivalvi e per il monitoraggio periodico delle zone di produzione e di stabulazione di molluschi bivalvi vivi (revisione 2014). Available from: http://www.sardegnasalute.it/index.php?xsl=316\&s $=9 \& \mathrm{v}=9$ $\& c=4695 \& n a=1 \& n=10$ 